\title{
Leukemic stem cells: from metabolic pathways and signaling to a new concept of drug resistance targeting
}

\author{
Jan Styczynski ${ }^{1 \bowtie}$ and Tomasz Drewa ${ }^{2}$ \\ ${ }^{1}$ Department of Pediatric Hematology and Oncology and ${ }^{2}$ Department of Biology, \\ Collegium Medicum, Nicolaus Copernicus University, Bydgoszcz, Poland
}

Received: 11 August, 2007; revised: 23 November, 2007; accepted: 04 December, 2007

available on-line: 13 December, 2007

\begin{abstract}
Cancer stem cells are a small subset of cancer cells constituting a reservoir of self-sustaining cells with the exclusive ability to self-renew and maintain the tumor. These cells are identified by specific stem cell markers: antigens, molecules and signaling pathways. Transcription factors and molecules associated with oncogenesis, such as NF-kB, Bmi-1, Notch, WNT beta-catenin, Sonic hedgehog and their biochemical pathways, active only in a small minority of cancer cells might play key roles in determining the biology and the overall long-term behavior of a tumor. The molecules and pathways specific for cancer stem cells, which contribute to their drug resistance, are potential targets for new therapeutic strategies.
\end{abstract}

Keywords: cancer stem cells, leukemic stem cells, drug resistance, metabolic pathways, stem cell markers

\section{THE CANCER STEM CELL HYPOTHESIS}

The observation of similarities between the self-renewal mechanisms of stem cells and of cancer cells has led to the new concept of the cancer stem cell. There are more and more data showing that the differentiation features of a tumor, morphological and architectural, are the key parameters used in routine clinical practice to define a tumor's primary origin. Tumors are not only monoclonal expansions of cells but might be sustained by a diseased "cancer stem cell" (CSC) population, which is endowed with the ability to self-renew and undergo aberrant differentiation (Reya et al., 2001; Clarke \& Fuller, 2006).

The cancer stem cells constitute a small subset of cancer cells being a reservoir of self-sustaining cells with the exclusive ability to self-renew and maintain the tumor. These cancer stem cells have the capacity to both divide and expand the cancer stem cell pool and to differentiate into the heterogeneous cancer cell types that in most cases appear to constitute the bulk of the cancer cells within the tumor.
Cancer stem cells, including leukemic stem cells (LSC), are supposed to arise from two potential pathways: (A) a stem cell losing growth regulation could directly become a cancer stem cell, or (B) a mature (i.e., differentiated or committed) cell could acquire the properties of self renewal and become a cancer stem cell (Cozzio et al., 2003; Korbling \& Estrov, 2003; Jamieson et al., 2004; Dean, 2006). A fraction of cells in a tumor are known to survive radiation treatment and cytotoxic drug exposure (Dean, 2006). Stem cells express drug transporters, DNA repair systems, and are refractory to programmed cell death. All these properties would allow cancer stem cells to resist our efforts to eliminate them (Zhou et al., 2001; Kim et al., 2002; Scharenberg et al., 2002).

\section{IDENTIFICATION OF STEM CELLS}

Most cells accumulate the fluorescent dyes Hoechst 33342 and rhodamine 123, but stem cells do not, as these compounds are effluxed by multi-

${ }^{\square}$ Corresponding author: Jan Styczynski, Department of Pediatric Hematology and Oncology, Collegium Medicum, Nicolaus Copernicus University, M. Curie-Sklodowskiej 9, 85-094 Bydgoszcz, Poland; tel: (48) 525854860 ; fax: (48) 52 585 4867; e-mail: jstyczynski@cm.umk.pl

Abbreviations: AML, acute myelogenous leukemia; CML, chronic myeloid leukemia; CSC, cancer stem cell(s); HSC, hematopoietic stem cell; LSC, leukemic stem cell; SP, side population. 
drug resistance proteins ABCG2 (BCRP) and ABCB1 (PGP), respectively. Thus, stem cells can be sorted out from among a population of non-stem ones because only they do not accumulate these fluorescent dyes. These cells might contain only a low level of Hoechst 33342 fluorescence and are referred to as "dull cells" or "side population" (SP) cells. The term side population was coined because during flow cytometry analysis, SP cells are visualized as a negatively stained "side population" to one side of the majority of cells on a density dot plot. A large fraction of hematopoietic stem cells (HSC) are found in the SP fraction. These SP cells can reconstitute the bone marrow (Goodell et al., 1996). SP cells can be isolated from many tissues, including the brain, breast, lung, heart, pancreas, testes, skin and liver, and these cells might represent lineage-specific stem cells (Goodell et al., 1996; Zhou et al., 2001; Asakura \& Rudnicki, 2002; Lechner et al., 2002; Alvi et al., 2003, Summer et al., 2003, Terunuma et al., 2003; Martin et al., 2004; Lassalle et al., 2004). However, currently there is no experimental evidence to support the claim that cancer stem cells from human solid epithelial tumors are selectively comprised within SP populations, and there is no robust information on their expression of multidrug resistance proteins. Hoechst 33342 staining of bone marrow from ABCG2-null mice fails to detect SP cells. However, the lack of SP cells in this case occurs not because these cells are absent, but because the lack of ABCG2 expression, which causes the accumulation of Hoechst dye (Dean et al., 2005).

Some of the stem cell markers are distributed widely throughout different tissues. Examples of broadly expressed stem cell markers are CD133, CXCR4, BMI-1, Musashi-1 antigen, and Oct-4 (Majka et al., 2005; Dean, 2006; Dalerba et al., 2007). Although stem cells have been discovered in many tissues, little is known regarding their phenotype. An exception is the hematopoietic stem cell (HSC), which represents a well defined cell in terms of function and phenotype. HSC is characterized as a Lin-negative/CD45-positive/CD34-positive/CD38negative cell.

\section{STEM CELL MARKERS}

All the different hematopoietic lineages can be fully and permanently reconstituted by transplantation of a very small population of cells, representing as little as $0.05 \%$ of total bone marrow. This cell population is characterized by a specific surface marker phenotype that, remarkably, is negative for expression of all lineage-specific differentiation antigens (Lin-negative) (Spangrude et al., 1988). Studies of acute myelogenous leukemia have shown that only $0.1-1 \%$ of all cells have leukemia-initiating activity (Lapidot et al., 1994).

Stem cell are not defined based solely on surface markers. None of the markers used to isolate stem cells in various normal and cancerous tissues is expressed exclusively by stem cells. For example, CD34 is present both on HSC and on acute myelogenous leukemia (AML) stem cells. CD133 was used to successfully enrich for brain tumor stem cells, but it is also present on normal brain stem cells and on many non-stem cells in various tumors and tissues. The same is true for other commonly used markers, such as CD44, Sca1, and Thy1. The vast majority of cells that express these markers are not stem cells. In addition, markers used to identify stem cells from one tissue are frequently not useful for identifying stem cells in other tissues: Sca-1 is useful for the identification of murine blood stem cells, but it is not consistently expressed by murine mammary duct stem cells. A given marker may or may not be useful for identifying stem cells from other tissues or tumor types (Clarke et al., 2006).

A common immunophenotype of leukemic stem cells with self-renewal potential has been identified. The surface phenotype of LSC in human AML is characterized by the CD34+CD38- phenotype in many AML subtypes, i.e. M1, M4, M5 (Bonnet \& Dick, 1997). In most cases their phenotype can be further specified as CD34+/CD38-/CD123+, while the CD123 antigen is also the $\alpha$ chain of IL3R (Jordan et al., 2000).

Another study demonstrated that most AML stem cells are quiescent (Guan et al., 2003). This finding means that these cells will survive standard chemotherapy directed to dividing cells. Isolation of quiescent leukemic stem cells was also reported in chronic myeloid leukemia (CML) (Holyoake et al., 1999). Treatment of CML patients with imatinib mesylate, which is otherwise highly effective in induction of remission, only suppresses the disease, since the drug is not able to destroy the leukemic stem cells, which are the root cause of the CML (Graham et al., 2002; Bhatia et al., 2003).

\section{THE LEUKEMIC STEM CELLS}

Primitive human LSC populations can be selected by cell surface CD34+/CD38-/CD123+ antigens. These cells are almost entirely quiescent, mimicking normal stem cells. As a result, agents that are active in dividing cells will not be effective in the quiescent population. As an alternative, it might be appropriate to consider as the target, other unique mechanisms that maintain the viability and survival of these cells. Two such pathways have been suggested: the PI3 kinase pathway (Xu et al., 2003) 
and NF-кB (Guzman et al., 2002), which are evident in LSC. Inhibiting these two pathways might have therapeutic relevance. Purified populations of LCS have been characterized by activation of the NF- $\kappa B$ pathway. Normal hematopoietic stem cells do not show activation of NF-kB. This is only a leukemiaspecific phenomenon. While no particular mutations or specific genetic events are associated with activation of the NF-kB or PI3-kinase pathways, converging events, such as multiple different mutations, may feed into these pathways. However, such pathway modification may not be the only mechanism to produce leukemia.

\section{MOLECULES AND SIGNALING PATHWAYS OF STEM CELL}

Biochemical pathways that are active in the majority of tumor cells might be of little functional relevance for the biology of CSC, whereas biochemical pathways active only in a small minority of cancer cells might play key roles in CSC biology and thus in the overall long-term behavior of a tumor (Dalerba et al., 2007). Differential expression of several transcription factors controls the fate of HSC and plays a critical role in the determination of selfrenewal, differentiation, and lineage commitment. These pathways are under the control of various intracellular stimuli as well as cytokines and stromal factors from adjacent cells in the bone marrow microenvironment.

It was found that the Bmi-1, Notch, WNT and Sonic hedgehog pathways, tumor suppressor genes and oncogenes are involved in regulation of self-renewal of both normal and cancer stem cells (Spink et al., 2000; Taipale \& Beachy, 2001; Andl et al., 2002; Jamora et al., 2003; Willert et al., 2003). Epigenetic signals play an important role, such as modification of chromatin structure, histone deacetylation, etc. Several studies suggest that epigenetic reprogramming is responsible for the loss of the neoplastic cell capacity to form tumors (Surani, 2001; Li et al., 2003a). The stem cell origin will determine the tumor type, with contributions by the genetic alternations of the individual and microenvironmental influences.

Transcription factors and cell cycle regulators associated with oncogenesis, such as Bmi-1 and Sonic hedgehog $(\mathrm{SHH})$, may play roles in the regulation of proliferation of both HSC and LSC (van der Lugt et al., 1996; Taipale \& Beachy, 2001). The BMI-1 oncogene is a member of the Polycomb group ring finger (PCGF) gene family. Its transcriptional activity was shown to be high in HSC and progressively down-regulated during hematopoietic differentiation (Lessard et al., 1998; Dimri et al., 2002). It is highly expressed in purified HSC and its expression de- clines with differentiation (Park et al., 2003). Bmi-1 seems to regulate stem cell renewal by modulating other genes that are important in cellular functions such as proliferation, survival, and lineage commitment (Park et al., 2003). BMI-1 has an essential role in regulating the proliferative potential of leukemic stem cells (Lessard \& Sauvageau, 2003). Although direct evidence for the role of $\mathrm{SHH}$ in the regulation of stem cell renewal is lacking, in vitro studies have shown increased self-renewal of HSC in response to $\mathrm{SHH}$, albeit in combination with other growth factors (Bhardwaj et al., 2001). Another molecule that is likely to play a key role in the molecular machinery of both HSC and LSC self-renewal is the protein phosphatase and tensin homologue (PTEN), a known tumor suppressor (Di Cristofano \& Pandolfi, 2000). Genes required for self-renewal of normal HSC can play opposite roles in the development of leukemia. In some cases they are necessary for longterm expansion of the transformed clone (BMI-1), but in others they act as tumor suppressors and prevent leukemic transformation (PTEN).

Other transcription factors such as the Homeobox (HOX) family members, including HOXB4, as well as the WNT signaling pathway have welldescribed roles in regulating the self-renewal and differentiation of HSC (Reya et al., 2003; Zhu et al., 2003). HOXB4 promotes the expansion of HSC without losing their ability to differentiate into normal lymphoid and myeloid cells (Sauvageau et al., 1995). It is abundantly expressed in HSC but declines as terminal differentiation proceeds (Sauvageau et al., 1995). Notably, deregulated expression of HOX family members such as HOXA9 is commonly observed in AML (Golub et al., 1999; Lawrence et al., 1999). The WNT signaling pathway has been shown to be critical to the development of several organs and recent studies have illustrated its important role in the regulation of hematopoietic stem and progenitor cell function (Reya et al., 2003; Staal \& Clevers, 2005).

The NOTCH protein is another protein important to the growth and differentiation of stem cells. NOTCH is processed by the enzyme $\gamma$-secretase, the same enzyme that processes the APP protein important in Alzheimer disease. The NOTCH/ Jagged pathway is important in regulating the integration of extracellular regulatory signals controlling HSC fate. Ligand binding leads to proteolytic cleavage and transport of the intracellular domain of NOTCH into the nucleus, where it is a transcription factor. In humans, contrary to what is observed in Drosophila, the NOTCH family of proteins comprises at least four members, and NOTCH-1 is the protein involved in HSC self-renewal and mutated in T-lineage acute lymphoblastic leukemia (Ellisen et al., 1991). Members of the NOTCH family have critical roles in keeping HSC in an undifferentiated state 
and may act as gatekeepers for factors governing self-renewal and lineage commitment (Ellisen et al., 1991; Pui et al., 1999).

Overexpression of $\beta$-catenin, a downstream activator of the WNT signaling pathway, expands the transplantable HSC pool in long-term cultures (Reya et al., 2001). Furthermore, activation of WNT signaling also increases the expression of other transcription factors and cell cycle regulators important in HSC renewal, such as HOXB4 and NOTCH-1 (Reya et al., 2003; Duncan et al., 2005).

One additional pathway important for the growth and differentiation of stem cells is the Hedgehog-Patched (HH-PTCH) pathway. Studies of the HH-PTCH pathway in tumors provide support for the importance of tumor stem cells in cancer, indicating that proliferation of normal stem cells is regulated by signals from surrounding normal cells. Transformation of these stem cells can lead to a premalignant stem cell with abnormal $\mathrm{HH}$ expression or deficient PTCH activity. Such cells can grow in an unrestrained manner, leading to local overgrowth. Additional genetic events give rise to a tumor stem cell that can generate more tumor stem cells as well as mature tumor cells. This model leads to specific hypotheses that can be tested as well as new avenues for therapeutics (Dean et al., 2005).

Studies on Drosophila and other developmental systems have identified regulatory pathways operative in embryonic cells (Nusslein-Volhard \& Wieschaus, 1980). One such pathway, involving the Hedgehog $(\mathrm{HH})$ and WNT signaling molecules, contains a large number of genes that can act as tumor suppressor genes or oncogenes in mammalian cells (Dean, 1997). Thus, Patched (PTCH) codes for the receptor that binds $\mathrm{HH}$ molecules and is mutated in patients with nevoid basal cell carcinoma syndrome (Hahn et al., 1996; Johnson et al., 1996). PTCH is also mutated in nearly all sporadic basal cell carcinomas and in some medulloblastomas (Bale \& Yu, 2001). The $H H$ genes (sonic hedgehog $(S H H)$, Indian hedgehog $(I H H)$, and desert hedgehog $(D H H))$ are overexpressed in a wide variety of cancers, including small-cell lung, pancreas, gastric, breast, and prostate (Berman et al., 2003; Thayer et al., 2003; Watkins et al., 2003; Karhadkar et al., 2004). HH family overexpression and $\mathrm{PTCH}$ mutation both have the effect of constitutive action of SMO (smoothened), a $G$ protein-coupled receptor that is a key signaling component of the pathway. Constitutive $\mathrm{HH}$ family expression could lead to stem cell activation and appears to be a common feature of many cancers.

The in vivo expression of human telomerase reverse transcriptase (hTERT) has repeatedly proven to be extremely heterogeneous among cancer cells (Yan et al., 2004; Dalerba et al., 2005). hTERT expression in epithelial cells can be upregulated by the
Bmi-1 protein during stem cell renewal (Dimri et al., 2002).

Recent research has delineated molecular pathways that regulate the self-renewal capacity of HSC. Self-renewal is the hallmark property of stem cells in both normal and neoplastic tissues. Several genes which encoded transcription factors have been identified, as well as cell cycle regulators that modulate the self renewal and differentiation of HSC (Zhu \& Emerson, 2002; Stein et al., 2004). Genes such as SCL, GATA-2, LMO-2, and AML-1 (also known as CBFA2 or RUNX1) govern the transcriptional regulation of early hematopoiesis, and the deregulation of these genes through chromosomal aberrations leads to several hematopoietic malignancies. The gene encoding the transcription factor SCL is the most frequent target of chromosomal rearrangements in children with T-cell acute lymphoblastic leukemia (Lecuyer \& Hoang, 2004). SCL is normally expressed in HSC and immature progenitors and is down-regulated as differentiation proceeds. As a result of chromosomal translocations, SCL is inappropriately expressed and, through collaboration with other oncoproteins, initiates malignant transformation (Lecuyer \& Hoang, 2004). Similarly, transcriptional activation of the $A M L-1$ gene is required for definitive hematopoiesis. As a result of translocation $\mathrm{t}(8 ; 21)$, the fusion protein AML-ETO, which is the result of one of the most frequent chromosomal abnormalities in AML, is generated (Licht, 2001). Constitutive expression of AML-ETO has been shown to increase the rate of self-renewal in stem cells (Mulloy et al., 2002). Of interest, such increased self-renewal is of no apparent pathogenic consequences, presumably because secondary mutations are necessary for the formation of the leukemic phenotype (de Guzman et al., 2002).

\section{MECHANISMS OF MULTIDRUG RESISTANCE}

Regarding possible mechanisms of drug resistance, an almost endless number can be envisaged along the signal transduction pathways triggered by these drugs. The most important groups of drug resistance mechanisms is shown in Fig. 1. Although chemotherapy kills most cells in a tumor, it probably leaves tumor stem cells behind, which might be an important mechanism of resistance. For example, the ATP-binding cassette $(\mathrm{ABC})$ drug transporters have been shown to protect stem cells from chemotherapeutic agents (Styczynski et al., 2002; Borowski et al., 2005; Dean et al., 2005). In a wide variety of stem cells, the ABC transporters are expressed causing drug resistance (Zhou et al., 2001; Styczynski, 2007; Styczynski et al., 2007). Normal HSC possess several characteristics that protect them from potential insults. LSC have similar properties, including 


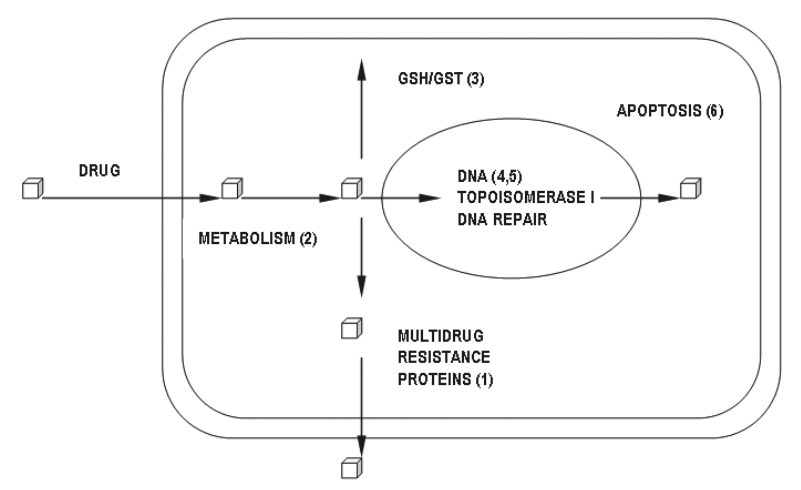

Figure 1. Main drug resistance mechanisms.

1. Multidrug resistance proteins. 2. Drug metabolism. 3. Glutathione and its transferases. 4. Molecular target. 5. DNA repair. 6. Apoptosis and its regulation.

quiescence (Guan et al., 2003), resistance to drugs and toxins through the expression of ATP-associated transporters (Dean et al., 2005), and resistance to apoptotic stimuli (Konopleva et al., 2002).

\section{ROLE OF ABC PROTEINS IN DRUG RESISTANCE}

One of the innate resistance mechanisms of stem cells is the expression of one or more out of 48 identified ATP-binding cassette (ABC) transporters (Table 1). These pumps play a role in protecting stem cells from xenobiotic toxins (Gottesman et al., 2002; Dean et al., 2005; Steinbach et al., 2006; Steinbach \& Legrand, 2007). Stem cells have many properties that distinguish them from mature, differentiated cells. In addition to their ability to self-renew and differentiate, they are quiescent, dividing infrequently. They also require specific environments comprising other cells, stroma and growth factors for their survival (Blanpain et al., 2004). One particularly intriguing property of stem cells is that they express high levels of specific $A B C$ drug transporters. For example, hematopoietic stem cells express high levels of ABCG2, while the ABCG2 gene is turned off in most committed progenitor and mature blood cells (Scharenberg et al., 2002). The two $A B C$ transporter-encoding genes that have been studied most extensively in stem cells are $A B C B 1$, which encodes P-glycoprotein (Gottesman et al., 2002), and ABCG2 (Doyle et al., 1998; Miyake et al., 1999; Kim et al., 2002; Scharenberg et al., 2002). $A B C G 2$ and $A B C B 1 / M D R 1$ genes are active in the vast majority of stem cells and in most tumor stem cells (Zhou et al., 2001; Kim et al., 2002; Scharenberg et al., 2002). These transporters can efflux fluorescent dyes such as rhodamine and Hoechst 33342, and this property allows the stem cells to be separated from non-stem cells on a cell sorter (Goodell et al., 1996). The combined use of chemotherapy drugs and $A B C$ transporter inhibitors could be emplyed to specifically target cancer stem cells (Dean, 2005; Dean \& Annilo, 2005; Dean et al., 2005). There are already highly specific inhibitors of $A B C B 1$ (PGP) in clinical use and ABCG2 (BCRP) inhibitors in development (Nowak et al., 2005; Pleban et al., 2005; Henrich et al., 2006). These therapies would be predicted to have toxic effects on the patient's normal stem cells. Both ABCG2 and ABCB1 play a role in the blood-brain barrier, which suggests that this approach would have to be carefully titrated to avoid excessive toxicity.

Along with $A B C C 1$, they represent the three principal multidrug-resistance genes that have been identified in tumor cells. Members of the ABC-transporter protein superfamily are promiscuous transporters of both hydrophobic and hydrophilic compounds (Dean et al., 2001; Gottesman et al., 2002). These transporters also have important roles in normal transport of drugs across the placenta and the intestine (more accurately, the retention of drugs in the intestinal lumen), and are important components of the blood-brain and blood-testis barriers. An important physiological role of $A B C$ transporters is protecting cells from toxins. The drug-transporting property within stem cells conferred by these ABC transporters is an important marker for isolation and analysis of hematopoietic stem cells.

Table 1. Most important multidrug resistance protein belonging to $\mathrm{ABC}$ family

\begin{tabular}{lll}
\hline Gene & Protein & Drugs transported by the protein \\
\hline$A B C A 2$ & ABCA2 & Estramustine \\
$A B C B 1$ & PGP/MDR & Doxorubicin, etoposide, vinblastine, paclitaxel \\
$A B C C 1$ & MRP1 & Doxorubicin, daunorubicin, vincristine, etoposide, camptothecine, methotrexate \\
$A B C C 2$ & MRP2 & Vinblastine, cisplatine, doxorubicin, methotrexate \\
$A B C C 3$ & MRP3 & Methotrexate, etoposide \\
$A B C C 4$ & MRP4 & 6-Mercaptopurine, 6-thioguanine, methotrexate and its metabolites \\
$A B C C 5$ & MRP5 & 6-Mercaptopurine, 6-thioguanine, methotrexate and its metabolites \\
$A B C C 6$ & MRP6 & Etoposide \\
$A B C C 11$ & MRP8 & 5-Fluorouracil \\
$A B C G 2$ & MXR/BCRP & Mitoxantrone, topotecan, doxorubicin, daunorubicin, irinotecan, methotrexate, imatinib \\
\hline
\end{tabular}




\section{MODELS OF DRUG RESISTANCE IN CANCER CELLS}

Cancer cells can acquire resistance to chemotherapy by a range of mechanisms, including gene mutation or over-expression of the drug target, inactivation of the drug, or elimination of the drug from the cell. Usually, tumors that recur after an initial response to chemotherapy are resistant to multiple drugs. Several models of drug resistance which can be connected with stem cells have been proposed (Fig. 2).

The first model postulates that a small percentage of cells in a population harbouring intrinsic mutations confer drug resistance (Goldie \& Coldman, 1979). This hypothesis would theorize that the cell acquiring the mutation is the stem cell. Although the expression of $\mathrm{ABC}$ transporters could render stem cells resistant to drugs, other determinants of resistance might be the DNA-repair capacity of the cell or the reluctance to enter apoptosis. Generally regarded as quiescent and non-dividing, stem cells would be expected to be inherently refractory to drugs that target the cell cycle, especially in rapidly dividing cells. New potent agents are able to overcome this mechanism of resistance. The ability of imatinib to induce apoptosis was unchanged in BCR-ABL-positive cells, previously blocked at G1/ $S$ phase. This indicates that imatinib is effective in non-dividing cells as well (Paterson et al., 2003).

The second, conventional model of drug resistance indicates that one or several cells in the tumor population acquire mutations and aberrations that confer drug resistance (Dean et al., 2005). These cells have a selective advantage that allows them to overtake the population of tumor cells following cancer chemotherapy.

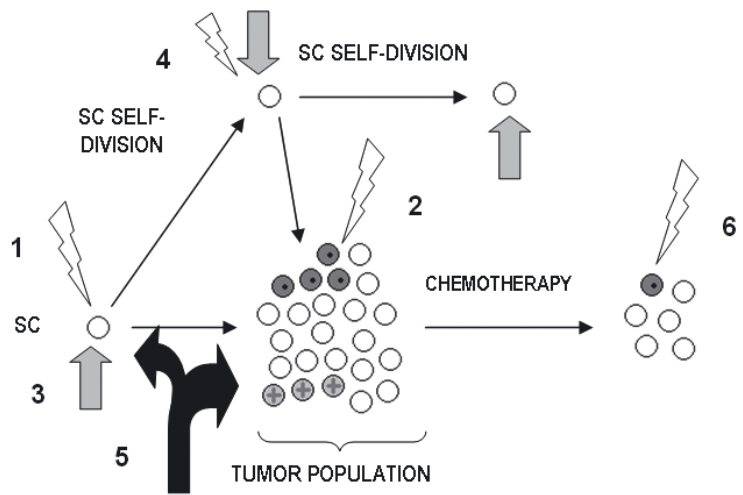

Figure 2. Models of drug resistance in cancer cells.

1. Stem cells (SC) harbor intrinsic mutations conferring drug resistance. 2. One or several cells in tumor population acquire mutation that confer drug resistance. 3. Resistance as a natural property of stem cell. 4 . Stem cells accumulate mutations over time. 5. Intrinsic drug resistance of SC and differentiated tumor cells. 6. Pluripotent cancer cells surviving chemotherapy develop drug resistance.
The third, alternative model based on the tumor stem cell concept, shows that the cancer stem cells are naturally resistant to chemotherapy through their quiescence, their capacity for DNA repair, and ABC-transporter expression. As a result, at least some of the tumor stem cells can survive chemotherapy and support regrowth of the tumor. Thus, model of resistance suggests that drug-resistant variants of the tumor stem cell or its close descendants arise, producing a population of multidrug-resistant tumor cells that can be found in many patients who have recurrence of their cancer following chemotherapy.

The fourth mechanism, based on the concept that stem cells accumulate mutations over time as a consequence of a long-term exposure to irradiation or chemical carcinogens, and cancer stem cells accumulate mutations that confer drug resistance to their abnormally developing offspring (Reya et al., 2001). Genetic alterations, as those that upregulate ABCB1 expression in human leukemia and lymphoma cells, could have originated in the stem cell (Mickley et al., 1997; Knutsen et al., 1998).

The fifth model indicates that both the stem cells and the variably differentiated cells are inherently drug-resistant, thus therapies have little or no effect, resulting in tumor growth ("intrinsic resistance"). An example of the latter is an intrinsically resistant cancer such as renal cancer, in which $A B C B 1$ is expressed in all cells and contributes to chemotherapy tolerance. In this case, the resistance phenotype of the cancer stem cell persists in the committed, abnormally developing progenitors that comprise the proliferative pool of cancer cells.

In the sixth model, tumors have a built-in population of drug-resistant pluripotent cells that can survive chemotherapy and regrow as cancer relapse (the cancer stem cell model of drug resistance). Normal stem cells can be found in stem cell-driven recovery of normal tissues following chemotherapy. This model can explain the rapid relapse observed clinically. It is also related to the repopulation of the bone marrow by normal hematopoietic stem cells or the recovery of the mucosa of the gastrointestinal tract, both of which usually occur within one 3-week cycle (Cotsarelis \& Millar, 2001; Sato et al., 2001).

\section{TARGETING DRUG RESISTANCE OF CANCER STEM CELLS}

The cancer stem cell hypothesis suggests that therapeutic approaches that do not eradicate the CSC compartment are not likely to achieve success. Only a majority of tumor cells might be killed and temporary regression can be achieved but this therapy will fail to prevent relapse or metastatic disease (Reya et al., 2001; Dalerba et al., 2007). In patients with acute 
myeloid leukemia, both normal and cancer stem cells mainly appear to be in a quiescent, nondividing, G0 state, thus being inherently resistant to the toxic effect of traditional chemotherapeutic regimens (Morrison \& Weissman, 1994; Guzman et al., 2002; Guan et al., 2003). Some agents, such as busulfan, are able to target cells in G0 state, causing a myeloablative effect. Ionizing radiation or busulfan can cause premature senescence of normal hematopoietic stem cells (Narita \& Lowe, 2005; Wang et al., 2006). The only rescue in these situations is hematopoietic stem cell transplantation.

The properties of leukemic stem cells indicate that current chemotherapy drugs will not be curative. The use of current cytotoxic agents is not effective in leukemia because the agents target both the leukemic and normal stem cell populations (Jordan, 2007). Such agents as cytarabine, anthracyclines, alkylating agents, nucleoside analogs, and topoisomerase inhibitors currently used in the treatment of acute leukemia show no activity with isolated LSC (Kantarjian et al., 1996; $\mathrm{Li}$ et al., 2003b). Since the nature of the LSC may vary depending upon the stage during which it arose, also the drug resistance and various characteristics that are relevant to therapy may differ, based on the origin of the malignant cell (Jordan, 2007).

Possibly, normal stem cells and progenitor cells are more sensitive than cancer stem cells to chemotherapy. DNA repair mechanisms within normal colon stem cells can be inhibited and thereby these cells undergo apoptosis in response to DNA damage. Due to this mechanism cells are protected from the accumulation of harmful mutations (Cairns, 2002).

\section{STRATEGIES TO OVERCOME LSC RESISTANCE TO THERAPY}

The primary challenge in developing treatment strategies targeted toward LSC is to identify pro-apoptotic stimuli that spare the normal HSC, while exerting a cytotoxic effect on LSC. A primary concern in the development of tumor stem cell-specific drugs is to overcome the inherent drug efflux pumps that are highly expressed in LSC. Several agents effective in inhibiting the ATP-binding cassette transporters have been studied and found to have limited clinical efficacy, such as cyclosporine or zosuquidar (List et al., 2001; Baer et al., 2002; Styczynski \& Wysocki, 2006). The biggest obstacle to this approach is the similarly high expression of these transporters in normal HSC, making them equally susceptible to these inhibitors (Dean et al., 2005).

Strategies directed at pathways that specifically regulate LSC survival would probably be more efficient (Jordan \& Guzman, 2004). The identification of survival pathways that are preferentially over-expressed in LSC suggests that differential activation of apoptosis mech- anisms in LSC should be possible (Guzman et al., 2001; 2002; 2005). The transcription factor NF-kB was found to be constitutively activated in LSC but not in normal HSC (Guzman et al., 2001). The antileukemic agent idarubicin is an NF- $\mathrm{\kappa B}$ inhibitor used in experimental models (Guzman et al., 2001; 2002). Another potent inhibitor of NF- $\mathrm{KB}$, parthenolide, can induce apoptosis in LSC while sparing normal HSC (Guzman et al., 2005). Constitutive activation of phosphatidylinositide-3 kinase is also necessary for LSC and its pharmacologic inhibition by LY294002 leads to a dose-dependent decrease in survival (Xu et al., 2003). Expression of transcription factors and their regulation by aberrant signaling pathways can influence the survival of LSC (Tani et al., 1996; Blair \& Pamphilon, 2003).

\section{CONCLUSIONS}

The concept of cancer as a stem cell disease has the potential to change significantly the view of the problem of drug resistance. There is now abundant evidence that stem cell properties are highly relevant to the biology of several human cancers. By separating the disease into a stem cell activation phase and a tumor progression phase, historical cancer studies can be reinterpreted with new understanding. Research efforts to discover the rules that govern the growth of tumor stem cells as well as to identify tumor stem cell antigens could lead to new targeted approaches. Cancer diagnostics, prevention, and therapeutics are likely to be greatly influenced by this new insight.

\section{REFERENCES}

Alvi AJ, Clayton H, Joshi C, Enver T, Ashworth A, Vivanco MM, Dale TC, Smalley MJ (2003) Functional and molecular characterisation of mammary side population cells. Breast Cancer Res 5: R1-8.

Andl T, Reddy ST, Gaddapara T, Millar SE (2002) WNT signals are required for the initiation of hair follicle development. Dev Cell 2: 643-653.

Asakura A, Rudnicki MA (2002) Side population cells from diverse adult tissues are capable of in vitro hematopoietic differentiation. Exp Hematol 30: 1339-1345.

Baer MR, George SL, Dodge RK, O'Loughlin KL, Minderman H, Caligiuri MA, Anastasi J, Powell BL, Kolitz JE, Schiffer CA, Bloomfield CD, Larson RA (2002) Phase 3 study of the multidrug resistance modulator PSC-833 in previously untreated patients 60 years of age and older with acute myeloid leukemia: Cancer and Leukemia Group B Study 9720. Blood 100: 1224-1232.

Bale AE, Yu KP (2001) The hedgehog pathway and basal cell carcinomas. Hum Mol Genet 10: 757-762.

Berman DM, Karhadkar SS, Maitra A, Montes De Oca R, Gerstenblith MR, Briggs K, Parker AR, Shimada Y, Eshleman JR, Watkins DN, Beachy PA (2003) Widespread requirement for Hedgehog ligand stimulation in growth of digestive tract tumours. Nature 425: 846-851.

Bhardwaj G, Murdoch B, Wu D, Baker DP, Williams KP, Chadwick K, Ling LE, Karanu FN, Bhatia M (2001) 
Sonic hedgehog induces the proliferation of primitive human hematopoietic cells via BMP regulation. Nat Immunol 2: 172-180.

Bhatia R, Holtz M, Niu N, Gray R, Snyder DS, Sawyers CL, Arber DA, Slovak ML, Forman SJ (2003) Persistence of malignant hematopoietic progenitors in chronic myelogenous leukemia patients in complete cytogenetic remission following imatinib mesylate treatment. Blood 101: 4701-4707.

Blair A, Pamphilon DH (2003) Leukaemic stem cells. Transfus Med 13: 363-375.

Blanpain C, Lowry WE, Geoghegan A, Polak L, Fuchs E (2004) Self-renewal, multipotency, and the existence of two cell populations within an epithelial stem cell niche. Cell 118: 635-648.

Bonnet D, Dick JE (1997) Human acute myeloid leukemia is organized as a hierarchy that originates from a primitive hematopoietic cell. Nat Med 3: 730-737.

Borowski E, Bontemps-Gracz MM, Piwkowska A (2005) Strategies for overcoming ABC-transporters-mediated multidrug resistance (MDR) of tumor cells. Acta Biochim Polon 52: 609-627.

Cairns J (2002) Somatic stem cells and the kinetics of mutagenesis and carcinogenesis. Proc Natl Acad Sci USA 99: 10567-10570.

Clarke MF, Fuller M (2006) Stem cells and cancer: two faces of eve. Cell 124: 1111-1115.

Clarke MF, Dick JE, Dirks PB, Eaves CJ, Jamieson $\mathrm{CH}$, Jones DL, Visvader J, Weissman IL, Wahl GM (2006) Cancer stem cells - perspectives on current status and future directions: AACR Workshop on Cancer Stem Cells. Cancer Res 66: 9339-9344.

Cotsarelis G, Millar SE (2001) Towards a molecular understanding of hair loss and its treatment. Trends Mol Med 7: 293-301.

Cozzio A, Passegue E, Ayton PM, Karsunky H, Cleary ML, Weissman IL (2003) Similar MLL-associated leukemias arising from self-renewing stem cells and short-lived myeloid progenitors. Genes Dev 17: 3029-3035.

Dalerba P, Guiducci C, Poliani PL, Cifola I, Parenza M, Frattini M, Gallino G, Carnevali I, Di Giulio I, Andreola S, Lombardo C, Rivoltini L, Schweighoffer T, Belli F, Colombo MP, Parmiani G, Castelli C (2005) Reconstitution of human telomerase reverse transcriptase expression rescues colorectal carcinoma cells from in vitro senescence: evidence against immortality as a constitutive trait of tumor cells. Cancer Res 65: 2321-2329.

Dalerba P, Cho RW, Clarke MF (2007) Cancer stem cells: models and concepts. Annu Rev Med 58: 267-284.

de Guzman CG, Warren AJ, Zhang Z, Gartland L, Erickson P, Drabkin H, Hiebert SW, Klug CA (2002) Hematopoietic stem cell expansion and distinct myeloid developmental abnormalities in a murine model of the AML1-ETO translocation. Mol Cell Biol 22: 5506-5517.

Dean M (1997) Towards a unified model of tumor suppression: lessons learned from the human patched gene. Biochim Biophys Acta 1332: M43-52.

Dean M (2005) The genetics of ATP-binding cassette transporters. Methods Enzymol 400: 409-429.

Dean M (2006) Cancer stem cells: redefining the paradigm of cancer treatment strategies. Mol Interv 6: 140-148.

Dean M, Annilo T (2005) Evolution of the ATP-binding cassette $(\mathrm{ABC})$ transporter superfamily in vertebrates. Annu Rev Genomics Hum Genet 6: 123-142.

Dean M, Hamon Y, Chimini G (2001) The human ATPbinding cassette (ABC) transporter superfamily. J Lipid Res 42: 1007-1017.

Dean M, Fojo T, Bates S (2005) Tumour stem cells and drug resistance. Nat Rev Cancer 5: 275-284.
Di Cristofano A, Pandolfi PP (2000) The multiple roles of PTEN in tumor suppression. Cell 100: 387-390.

Dimri GP, Martinez JL, Jacobs JJ, Keblusek P, Itahana K, Van Lohuizen M, Campisi J, Wazer DE, Band V (2002) The Bmi-1 oncogene induces telomerase activity and immortalizes human mammary epithelial cells. Cancer Res 62: 4736-4745.

Doyle LA, Yang W, Abruzzo LV, Krogmann T, Gao Y, Rishi AK, Ross DD (1998) A multidrug resistance transporter from human MCF-7 breast cancer cells. Proc Natl Acad Sci USA 95: 15665-15670.

Duncan AW, Rattis FM, DiMascio LN, Congdon KL, Pazianos G, Zhao C, Yoon K, Cook JM, Willert K, Gaiano N, Reya T (2005) Integration of Notch and Wnt signaling in hematopoietic stem cell maintenance. Nat Immunol 6: 314-322.

Ellisen LW, Bird J, West DC, Soreng AL, Reynolds TC, Smith SD, Sklar J (1991) TAN-1, the human homolog of the Drosophila notch gene, is broken by chromosomal translocations in T lymphoblastic neoplasms. Cell 66: 649-661.

Goldie JH, Coldman AJ (1979) A mathematic model for relating the drug sensitivity of tumors to their spontaneous mutation rate. Cancer Treat Rep 63: 1727-1733.

Golub TR, Slonim DK, Tamayo P, Huard C, Gaasenbeek M, Mesirov JP, Coller H, Loh ML, Downing JR, Caligiuri MA, Bloomfield CD, Lander ES (1999) Molecular classification of cancer: class discovery and class prediction by gene expression monitoring. Science 286: 531-537.

Goodell MA, Brose K, Paradis G, Conner AS, Mulligan RC (1996) Isolation and functional properties of murine hematopoietic stem cells that are replicating in vivo. J Exp Med 183: 1797-1806.

Gottesman MM, Fojo T, Bates SE (2002) Multidrug resistance in cancer: role of ATP-dependent transporters. Nat Rev Cancer 2: 48-58.

Graham SM, Jorgensen HG, Allan E, Pearson C, Alcorn MJ, Richmond L, Holyoake TL (2002) Primitive, quiescent, Philadelphia-positive stem cells from patients with chronic myeloid leukemia are insensitive to STI571 in vitro. Blood 99: 319-325.

Guan Y, Gerhard B, Hogge DE (2003) Detection, isolation, and stimulation of quiescent primitive leukemic progenitor cells from patients with acute myeloid leukemia (AML). Blood 101: 3142-3149.

Guzman ML, Neering SJ, Upchurch D, Grimes B, Howard DS, Rizzieri DA, Luger SM, Jordan CT (2001) Nuclear factor-kappaB is constitutively activated in primitive human acute myelogenous leukemia cells. Blood 98: 2301-2307.

Guzman ML, Swiderski CF, Howard DS, Grimes BA, Rossi RM, Szilvassy SJ, Jordan CT (2002) Preferential induction of apoptosis for primary human leukemic stem cells. Proc Natl Acad Sci USA 99: 16220-16225.

Guzman ML, Rossi RM, Karnischky L, Li X, Peterson DR, Howard DS, Jordan CT (2005) The sesquiterpene lactone parthenolide induces apoptosis of human acute myelogenous leukemia stem and progenitor cells. Blood 105: 4163-4169.

Hahn H, Wicking C, Zaphiropoulous PG, Gailani MR, Shanley S, Chidambaram A, Vorechovsky I, Holmberg E, Unden AB, Gillies S, Negus K, Smyth I, Pressman C, Leffell DJ, Gerrard B, Goldstein AM, Dean M, Toftgard R, Chenevix-Trench G, Wainwright B, Bale AE (1996) Mutations of the human homolog of Drosophila patched in the nevoid basal cell carcinoma syndrome. Cell 85: 841-851. 
Henrich CJ, Bokesch HR, Dean M, Bates SE, Robey RW, Goncharova EI, Wilson JA, McMahon JB (2006) A highthroughput cell-based assay for inhibitors of ABCG2 activity. J Biomol Screen 11: 176-183.

Holyoake T, Jiang X, Eaves C, Eaves A (1999) Isolation of a highly quiescent subpopulation of primitive leukemic cells in chronic myeloid leukemia. Blood 94: 2056-2064.

Jamieson $\mathrm{CH}$, Ailles LE, Dylla SJ, Muijtjens M, Jones C, Zehnder JL, Gotlib J, Li K, Manz MG, Keating A, Sawyers CL, Weissman IL (2004) Granulocyte-macrophage progenitors as candidate leukemic stem cells in blastcrisis CML. N Engl J Med 351: 657-667.

Jamora C, DasGupta R, Kocieniewski P, Fuchs E (2003) Links between signal transduction, transcription and adhesion in epithelial bud development. Nature 422: 317-322.

Johnson RL, Rothman AL, Xie J, Goodrich LV, Bare JW, Bonifas JM, Quinn AG, Myers RM, Cox DR, Epstein EH Jr, Scott MP (1996) Human homolog of patched, a candidate gene for the basal cell nevus syndrome. Science 272: $1668-1671$.

Jordan CT (2007) The leukemic stem cell. Best Pract Res Clin Haematol 20: 13-18.

Jordan CT, Guzman ML (2004) Mechanisms controlling pathogenesis and survival of leukemic stem cells. Oncogene 23: 7178-7187.

Jordan CT, Upchurch D, Szilvassy SJ, Guzman ML, Howard DS, Pettigrew AL, Meyerrose T, Rossi R, Grimes B, Rizzieri DA, Luger SM, Phillips GL (2000) The interleukin-3 receptor alpha chain is a unique marker for human acute myelogenous leukemia stem cells. Leukemia 14: 1777-1784.

Kantarjian HM, Estey EH, Keating MA (1996) New chemotherapeutic agents in acute myeloid leukemia. Leukemia 10 (Suppl 1): S4-6.

Karhadkar SS, Bova GS, Abdallah N, Dhara S, Gardner D, Maitra A, Isaacs JT, Berman DM, Beachy PA (2004) Hedgehog signalling in prostate regeneration, neoplasia and metastasis. Nature 431: 707-712.

Kim M, Turnquist H, Jackson J, Sgagias M, Yan Y, Gong M, Dean M, Sharp JG, Cowan K (2002) The multidrug resistance transporter ABCG2 (breast cancer resistance protein 1) effluxes Hoechst 33342 and is overexpressed in hematopoietic stem cells. Clin Cancer Res 8: 22-28.

Knutsen T, Mickley LA, Ried T, Green ED, du Manoir S, Schrock E, Macville M, Ning Y, Robey R, Polymeropoulos M, Torres R, Fojo T (1998) Cytogenetic and molecular characterization of random chromosomal rearrangements activating the drug resistance gene, MDR1/P-glycoprotein, in drug-selected cell lines and patients with drug refractory ALL. Genes Chromosomes Cancer 23: 44-54.

Konopleva M, Zhao S, Hu W, Jiang S, Snell V, Weidner D, Jackson CE, Zhang X, Champlin R, Estey E, Reed JC, Andreeff M (2002) The anti-apoptotic genes Bcl-X(L) and $\mathrm{Bcl}-2$ are over-expressed and contribute to chemoresistance of non-proliferating leukaemic CD34+ cells. Br J Haematol 118: 521-534.

Korbling M, Estrov Z (2003) Adult stem cells for tissue repair - a new therapeutic concept? $N$ Engl J Med 349: 570-582.

Lapidot T, Sirard C, Vormoor J, Murdoch B, Hoang T, Caceres-Cortes J, Minden M, Paterson B, Caligiuri MA, Dick JE (1994) A cell initiating human acute myeloid leukaemia after transplantation into SCID mice. Nature 367: 645-648.

Lassalle B, Bastos H, Louis JP, Riou L, Testart J, Dutrillaux B, Fouchet P, Allemand I (2004) 'Side Population' cells in adult mouse testis express Bcrp1 gene and are en- riched in spermatogonia and germinal stem cells. Development 131: 479-487.

Lawrence HJ, Rozenfeld S, Cruz C, Matsukuma K, Kwong A, Komuves L, Buchberg AM, Largman C (1999) Frequent co-expression of the HOXA9 and MEIS1 homeobox genes in human myeloid leukemias. Leukemia 13: 1993-1999.

Lechner A, Leech CA, Abraham EJ, Nolan AL, Habener JF (2002) Nestin-positive progenitor cells derived from adult human pancreatic islets of Langerhans contain side population (SP) cells defined by expression of the ABCG2 (BCRP1) ATP-binding cassette transporter. Biochem Biophys Res Commun 293: 670-674.

Lecuyer E, Hoang T (2004) SCL: from the origin of hematopoiesis to stem cells and leukemia. Exp Hematol 32: $11-24$.

Lessard J, Baban S, Sauvageau G (1998) Stage-specific expression of polycomb group genes in human bone marrow cells. Blood 91: 1216-1224.

Lessard J, Sauvageau G (2003) Bmi-1 determines the proliferative capacity of normal and leukaemic stem cells. Nature 423: 255-260.

Li L, Connelly MC, Wetmore C, Curran T, Morgan JI (2003a) Mouse embryos cloned from brain tumors. Cancer Res 63: 2733-2736.

Li TK, Houghton PJ, Desai SD, Daroui P, Liu AA, Hars ES, Ruchelman AL, LaVoie EJ, Liu LF (2003b) Characterization of ARC-111 as a novel topoisomerase I-targeting anticancer drug. Cancer Res 63: 8400-8407.

Licht JD (2001) AML1 and the AML1-ETO fusion protein in the pathogenesis of $\mathrm{t}(8 ; 21)$ AML. Oncogene 20: 56605679.

List AF, Kopecky KJ, Willman CL, Head DR, Persons DL, Slovak ML, Dorr R, Karanes C, Hynes HE, Doroshow JH, Shurafa M, Appelbaum FR (2001) Benefit of cyclosporine modulation of drug resistance in patients with poor-risk acute myeloid leukemia: a Southwest Oncology Group study. Blood 98: 3212-3220.

Majka M, Kucia M, Ratajczak MZ (2005) Stem cell biology - a never ending quest for understanding. Acta Biochim Polon 52: 353-358.

Martin CM, Meeson AP, Robertson SM, Hawke TJ, Richardson JA, Bates S, Goetsch SC, Gallardo TD, Garry DJ (2004) Persistent expression of the ATP-binding cassette transporter, Abcg2, identifies cardiac SP cells in the developing and adult heart. Dev Biol 265: 262-275.

Mickley LA, Spengler BA, Knutsen TA, Biedler JL, Fojo T (1997) Gene rearrangement: a novel mechanism for MDR-1 gene activation. J Clin Invest 99: 1947-1957.

Miyake K, Mickley L, Litman T, Zhan Z, Robey R, Cristensen B, Brangi M, Greenberger L, Dean M, Fojo T, Bates SE (1999) Molecular cloning of cDNAs which are highly overexpressed in mitoxantrone-resistant cells: demonstration of homology to $\mathrm{ABC}$ transport genes. Cancer Res 59: 8-13.

Morrison SJ, Weissman IL (1994) The long-term repopulating subset of hematopoietic stem cells is deterministic and isolatable by phenotype. Immunity 1: 661-673.

Mulloy JC, Cammenga J, MacKenzie KL, Berguido FJ, Moore MA, Nimer SD (2002) The AML1-ETO fusion protein promotes the expansion of human hematopoietic stem cells. Blood 99: 15-23.

Narita M, Lowe SW (2005) Senescence comes of age. Nat Med 11: 920-922.

Nowak R, Baranowska-Bosiacka I, Stefanska B, Machalinski B, Hlynczak AJ, Tarasiuk J (2005) The effect of new non-cross resistant antitumour agents on the energy state of human erythrocytes. Acta Biochim Polon 52: 953-957. 
Nusslein-Volhard C, Wieschaus E (1980) Mutations affecting segment number and polarity in Drosophila. Nature 287: 795-801.

Park IK, Qian D, Kiel M, Becker MW, Pihalja M, Weissman IL, Morrison SJ, Clarke MF (2003) Bmi-1 is required for maintenance of adult self-renewing haematopoietic stem cells. Nature 423: 302-305.

Paterson SC, Smith KD, Holyoake TL, Jorgensen HG (2003) Is there a cloud in the silver lining for imatinib? $\mathrm{Br} \mathrm{J}$ Cancer 88: 983-987.

Pleban K, Kaiser D, Kopp S, Peer M, Chiba P, Ecker GF (2005) Targeting drug-efflux pumps - a pharmacoinformatic approach. Acta Biochim Polon 52: 737-740.

Pui JC, Allman D, Xu L, DeRocco S, Karnell FG, Bakkour S, Lee JY, Kadesch T, Hardy RR, Aster JC, Pear WS (1999) Notch1 expression in early lymphopoiesis influences $\mathrm{B}$ versus $\mathrm{T}$ lineage determination. Immunity 11: 299-308.

Reya T, Morrison SJ, Clarke MF, Weissman IL (2001) Stem cells, cancer, and cancer stem cells. Nature 414: 105111.

Reya T, Duncan AW, Ailles L, Domen J, Scherer DC, Willert K, Hintz L, Nusse R, Weissman IL (2003) A role for Wnt signalling in self-renewal of haematopoietic stem cells. Nature 423: 409-414.

Sato N, Leopold PL, Crystal RG (2001) Effect of adenovirus-mediated expression of Sonic hedgehog gene on hair regrowth in mice with chemotherapy-induced alopecia. J Natl Cancer Inst 93: 1858-1864.

Sauvageau G, Thorsteinsdottir U, Eaves CJ, Lawrence HJ, Largman C, Lansdorp PM, Humphries RK (1995) Overexpression of HOXB4 in hematopoietic cells causes the selective expansion of more primitive populations in vitro and in vivo. Genes Dev 9: 1753-1765.

Scharenberg CW, Harkey MA, Torok-Storb B (2002) The ABCG2 transporter is an efficient Hoechst 33342 efflux pump and is preferentially expressed by immature human hematopoietic progenitors. Blood 99: 507-512.

Spangrude GJ, Heimfeld S, Weissman IL (1988) Purification and characterization of mouse hematopoietic stem cells. Science 241: 58-62.

Spink KE, Polakis P, Weis WI (2000) Structural basis of the Axin-adenomatous polyposis coli interaction. EMBO J 19: $2270-2279$.

Staal FJ, Clevers HC (2005) WNT signalling and haematopoiesis: a WNT-WNT situation. Nat Rev Immunol 5: 21-30.

Stein MI, Zhu J, Emerson SG (2004) Molecular pathways regulating the self-renewal of hematopoietic stem cells. Exp Hematol 32: 1129-1136.

Steinbach D, Legrand O (2007) ABC transporters and drug resistance in leukemia: was P-gp nothing but the first head of the Hydra? Leukemia 21: 1172-1176.

Steinbach D, Gillet JP, Sauerbrey A, Gruhn B, Dawczynski K, Bertholet V, de Longueville F, Zintl F, Remacle J, Efferth T (2006) ABCA3 as a possible cause of drug resistance in childhood acute myeloid leukemia. Clin Cancer Res 12: 4357-4363.

Styczynski J (2007) Drug resistance in childhood acute myeloid leukemia. Curr Pharm Biotechnol 8: 59-75.

Styczynski J, Wysocki M (2006) Ex vivo modulation of response to prednisolone in childhood acute lymphoblastic leukaemia. Br J Haematol 133: 397-399.

Styczynski J, Wysocki M, Debski R, Kurylak A, Balwierz W, Rokicka-Milewska R, Matysiak M, Balcerska A, Kowalczyk J, Wachowiak J, Sonta-Jakimczyk D, Chybicka A (2002) The influence of intracellular idarubicin and daunorubicin levels on drug cytotoxicity in childhood acute leukemia. Acta Biochim Polon 49: 99-107.

Styczynski J, Wysocki M, Debski R, Czyzewski K, Kolodziej B, Rafinska B, Kubicka M, Koltan S, Koltan A, Pogorzala M, Kurylak A, Olszewska-Slonina D, Balwierz W, Juraszewska E, Wieczorek M, Olejnik I, KrawczukRybak M, Kuzmicz M, Kowalczyk J, Stefaniak J, Badowska W, Sonta-Jakimczyk D, Szczepanski T, Matysiak M, Malinowska I, Stanczak E (2007) Predictive value of multidrug resistance proteins and cellular drug resistance in childhood relapsed acute lymphoblastic leukemia. J Cancer Res Clin Oncol 133: 875-893.

Summer R, Kotton DN, Sun X, Ma B, Fitzsimmons K, Fine A (2003) Side population cells and Bcrp1 expression in lung. Am J Physiol Lung Cell Mol Physiol 285: L97-104.

Surani MA (2001) Reprogramming of genome function through epigenetic inheritance. Nature 414: 122-128.

Taipale J, Beachy PA (2001) The Hedgehog and Wnt signalling pathways in cancer. Nature 411: 349-354.

Tani T, Ylanne J, Virtanen I (1996) Expression of megakaryocytic and erythroid properties in human leukemic cells. Exp Hematol 24: 158-168.

Terunuma A, Jackson KL, Kapoor V, Telford WG, Vogel JC (2003) Side population keratinocytes resembling bone marrow side population stem cells are distinct from label-retaining keratinocyte stem cells. J Invest Dermatol 121: 1095-1103.

Thayer SP, di Magliano MP, Heiser PW, Nielsen CM, Roberts DJ, Lauwers GY, Qi YP, Gysin S, Fernandez-del Castillo C, Yajnik V, Antoniu B, McMahon M, Warshaw AL, Hebrok M (2003) Hedgehog is an early and late mediator of pancreatic cancer tumorigenesis. $\mathrm{Na}$ ture 425: 851-856.

van der Lugt NM, Alkema M, Berns A, Deschamps J (1996) The Polycomb-group homolog Bmi-1 is a regulator of murine Hox gene expression. Mech Dev 58: 153-164.

Wang Y, Schulte BA, LaRue AC, Ogawa M, Zhou D (2006) Total body irradiation selectively induces murine hematopoietic stem cell senescence. Blood 107: 358-366.

Watkins DN, Berman DM, Burkholder SG, Wang B, Beachy PA, Baylin SB (2003) Hedgehog signalling within airway epithelial progenitors and in small-cell lung cancer. Nature 422: 313-317.

Willert K, Brown JD, Danenberg E, Duncan AW, Weissman IL, Reya T, Yates JR $3^{\text {rd }}$, Nusse R (2003) Wnt proteins are lipid-modified and can act as stem cell growth factors. Nature 423: 448-452.

Xu Q, Simpson SE, Scialla TJ, Bagg A, Carroll M (2003) Survival of acute myeloid leukemia cells requires PI3 kinase activation. Blood 102: 972-980.

Yan P, Benhattar J, Seelentag W, Stehle JC, Bosman FT (2004) Immunohistochemical localization of hTERT protein in human tissues. Histochem Cell Biol 121: 391-397.

Zhu J, Emerson SG (2002) Hematopoietic cytokines, transcription factors and lineage commitment. Oncogene 21: 3295-3313.

Zhou S, Schuetz JD, Bunting KD, Colapietro AM, Sampath J, Morris JJ, Lagutina I, Grosveld GC, Osawa M, Nakauchi H, Sorrentino BP (2001) The ABC transporter Bcrp1/ABCG2 is expressed in a wide variety of stem cells and is a molecular determinant of the side-population phenotype. Nat Med 7: 1028-1034.

Zhu J, Giannola DM, Zhang Y, Rivera AJ, Emerson SG (2003) NF-Y cooperates with USF1/2 to induce the hematopoietic expression of HOXB4. Blood 102: 24202427. 